The Journal of Vitaminologi 6, 132-138 (1960)

\title{
THE FREE AND BOUND FORMS OF THE SERUM VITAMIN B 12 IN VARIOUS ANIMAL SPECIES
}

\author{
NOBUO KATO \\ Department of Bacteriology, Nagoya University School of Medicine, \\ Showa, Nagoya
}

(Received January 20, 1960)

\begin{abstract}
When vitamin $B_{12}\left(B_{12}\right)$ in the serum is determined microbiologically, two forms are distinguishable, of which the "free" or "easily available" form has a growth-promoting activity on the assay organisms without any treatment of the serum, whereas the "bound" form is activated through liberation by heating or enzymatic digestion from the protein with which it is bound $(1,2)$. The physiological roles of the two forms have not yet been clarified. From the fact that the major part of $B_{12}$ in normal human serum consists of the bound form, some investigators have assumed that the bound form is physiologically active or hematopoiesis-promoting $(3,4,5)$, whereas in another study the free form has been considered to have a direct hematopoiesis-promoting action (6).

While studying the serum $B_{12}$ in various animal species of mammals, it has been found that the ratio of the free form to the total serum $B_{12}$ levels varies remarkably according to the animal species. These results are presented in the resent report. Some reports have already appeared concerning the $B_{12}$ activity of the plasma or serum of various animal species $(7,8)$, without distinguishing the free form from the bound.
\end{abstract}

\section{MATERIALS AND METHODS}

Serum Samples Examined The sera of the mouse, rat, guinea pig, rabbit, dog, horse, cow and calf were examined. The mice, rats, guinea pigs and rabbits had been kept on natural diets in our laboratory. Adult animals of both sexes were used. The mice used weighed from 20 to $25 \mathrm{~g}$, rats from 200 to $250 \mathrm{~g}$, guinea pigs from 500 to $600 \mathrm{~g}$, and rabbits from 2.5 to $3.0 \mathrm{~kg}$. Mouse serum was separated from the collected blood of five mice. Dog blood was given by the Second Department of Surgery, Nagoya University School of Medicine. Bloods of horses, cattle and calves were obtained from the slaughter house of Nagoya City. Anemic blood was excluded from the test samples by the determination using hematocrits.

Vitamin $B_{12}$ Determination — Microbiological assay with Lactobacillus leichmannii ATCC 4797 was used. The treatment of the sera and the procedure for the assay were described previously $(1,9)$. The liver $B_{12}$ levels were 
also determined by the same procedures as described in a previous paper (9). The determination of alkali-stable fraction of $B_{12}$ activity in the serum and liver was neglected due to the reason stated previously $(1,10)$. Bacto $B_{12}$ Assay Medium USP "Difco" was used throughout the present study.

\section{RESULTS}

The total and free form levels of the serum $B_{12}$ of the mouse, rat, guinea pig, rabbit, dog, cow and calf are shown in Tables I-VI. The bound form of the serum $B_{12}$ can be obtained by subtracting the value of the free form from the total. It is seen in the Tables that the total $B_{12}$ levels of the serum and the ratio of the free form to the total $B_{12}$ levels varied remarkably according to the animal species. Even in the same animal species the total and free form levels of the serum $B_{12}$ fluctuated in relatively wide ranges, but the differences of the total $B_{12}$ and of the ratios of the free form to the total were fairly distinct among the various animal species.

TABLE I

Serum Vitamin $B_{12}$ Levels of Mice

\begin{tabular}{|c|c|c|c|}
\hline No. of serum ${ }^{a}$ & Free $B_{12}$ & Total $\mathrm{B}_{12}$ & Free/total \\
\hline & $m \mu g / m l$ & $m \mu g / m l$ & $\%$ \\
\hline 1 & $0^{b}$ & 7.20 & 0 \\
\hline 2 & 0 & 6.70 & 0 \\
\hline 3 & 0 & 6.65 & 0 \\
\hline 4 & 0 & 6.95 & 0 \\
\hline Mean & 0 & 6.88 & 0 \\
\hline
\end{tabular}

${ }^{a}$ A serum sample was separated from the collected blood of five mice.

${ }^{b}$ Less than $0.01 \mathrm{~m} \mu \mathrm{g}$.

TABLE II

Serum Vitamin $B_{12}$ Levels of Rats

\begin{tabular}{cccc} 
No. of serum & Free $\mathrm{B}_{\mathbf{1 2}}$ & Total $\mathrm{B}_{\mathbf{1 2}}$ & Free/total \\
\hline & $m \mu \mathrm{g} / m \boldsymbol{l}$ & $m \mu g / m l$ & $\%$ \\
1 & 0.22 & 0.63 & 35.2 \\
2 & 0.30 & 1.05 & 28.6 \\
3 & 0.24 & 0.80 & 30.0 \\
4 & 0.20 & 0.54 & 37.4 \\
5 & 0.15 & 0.51 & 35.4 \\
6 & 0.32 & 0.90 & 28.0 \\
7 & 0.35 & 1.25 & 77.3 \\
8 & 0.34 & 0.44 & 25.0 \\
9 & 0.16 & 0.64 & $\mathbf{3 6 . 3}$ \\
\hline
\end{tabular}

The ranges and average values of the total and free form levels of the serum $B_{12}$ of the various animal species are summarized in Table VII together 
TABLE III

Serum Vitamin $B_{12}$ Levels of Guinea Pigs

\begin{tabular}{cccc}
\hline No. of serum & Free $\mathrm{B}_{\mathbf{1 2}}$ & Total $\mathrm{B}_{\mathbf{1 2}}$ & Free/total \\
\hline & $m \mu \mathrm{g} / m l$ & $m \mu \mathrm{g} / m l$ & $\%$ \\
1 & 1.60 & 1.89 & 85.5 \\
2 & 0.68 & 6.47 & 93.9 \\
3 & 2.56 & 2.86 & 89.5 \\
4 & 1.84 & 2.27 & 94.3 \\
5 & 0.66 & 0.70 & 94.2 \\
6 & 0.65 & 0.69 & $\mathbf{8 9 . 7}$ \\
\hline
\end{tabular}

TABLE IV

Serum Vitamin $B_{12}$ Levels of Rabbits

\begin{tabular}{cccc}
\hline \hline No. of serum $^{a}$ & Free $\mathrm{B}_{\mathbf{1 2}}$ & Total $\mathrm{B}_{\mathbf{1 2}}$ & Free/total \\
\hline & $m \mu \mathrm{\mu} / \mathrm{ml}$ & $m \mu g / m l$ & $\%$ \\
2 & 19.0 & 67.0 & 28.3 \\
3 & 10.5 & 49.0 & 21.4 \\
4 & 14.4 & 36.0 & 40.0 \\
5 & 29.6 & 72.0 & 41.1 \\
6 & 26.3 & 49.0 & 49.6 \\
7 & 21.8 & 44.0 & 25.6 \\
8 & 12.5 & 50.0 & 29.7 \\
9 & 15.0 & 40.5 & 34.4 \\
10 & 14.8 & 43.0 & 61.3 \\
Mean & 9.8 & 16.0 & $\mathbf{3 8 . 4}$ \\
\hline
\end{tabular}

${ }^{a}$ The serum samples were the same as in a previous report (9).

$\mathrm{T}_{\text {ABLE }} \mathrm{V}$

Serum Vitamin $B_{12}$ Levels of Dogs

\begin{tabular}{cccc}
\hline No. of serum & Free $\mathrm{B}_{\mathbf{1 2}}$ & Total $\mathrm{B}_{\mathbf{1 2}}$ & Free/total \\
\hline & $m \mu \mathrm{g} / \mathrm{ml}$ & $m \mu \mathrm{g} / m \boldsymbol{m}$ & $\%$ \\
1 & 0.22 & 0.96 & 23.9 \\
2 & 0.21 & 1.11 & 19.8 \\
3 & 0.20 & 1.14 & 17.5 \\
4 & 0.17 & 0.84 & 37.2 \\
5 & 0.20 & 0.54 & $\mathbf{2 3 . 7}$ \\
\hline
\end{tabular}

with the data on human serum cited from a previous report (1). The total $B_{12}$ levels of the various species could be ranged from high to low as follows : rabbit, mouse, horse, guinea pig, dog, rat, calf, cow and human. A1though the differences of the total $\mathrm{B}_{12}$ levels among the last five species were minute, rabbit serum had about 100 times and mouse serum about ten times as high $B_{12}$ levels as the last five animal species. The ratios of the free 
TABLE VI

Serum Vitamin $B_{12}$ Levels of Horses, Cattle and Calves

\begin{tabular}{rccc}
\hline No. ot serum & Free $\mathrm{B}_{\mathbf{1 2}}$ & Total $\mathrm{B}_{\mathbf{1 2}}$ & Free/total \\
\hline & $m \mu \mathrm{g} / \mathrm{ml}$ & $m \mu \mathrm{g} / m l$ & $\%$ \\
Horse 1 & 1.08 & 2.20 & 49.1 \\
2 & 3.12 & 3.44 & 57.1 \\
3 & 1.62 & 2.84 & $\mathbf{6 5 . 4}$ \\
\hline Mean & $\mathbf{1 . 9 4}$ & $\mathbf{2 . 8 3}$ & 9.3 \\
Cow 1 & 0.04 & 0.43 & 10.9 \\
2 & 0.07 & 0.64 & $\mathbf{1 0 . 1}$ \\
Mean & $\mathbf{0 . 0 6}$ & $\mathbf{0 . 5 4}$ & 52.5 \\
Calf 1 & 0.21 & 0.40 & 30.6 \\
2 & 0.22 & 0.72 & $\mathbf{4 1 . 6}$ \\
Mean & $\mathbf{0 . 2 2}$ & $\mathbf{0 . 5 6}$ &
\end{tabular}

TABLE VII

Serum Vitamin $B_{12}$ Levels of Various Animal Species

\begin{tabular}{|c|c|c|c|c|c|c|c|}
\hline \multirow{3}{*}{$\begin{array}{l}\text { Animal } \\
\text { species }\end{array}$} & \multirow{3}{*}{$\begin{array}{c}\text { Number } \\
\text { of } \\
\text { animals }\end{array}$} & \multicolumn{4}{|c|}{ Serum $\mathrm{B}_{12}$ Levels $(m \mu g / m l)$} & \multirow{2}{*}{\multicolumn{2}{|c|}{ Free/total (\%) }} \\
\hline & & \multicolumn{2}{|c|}{ Free } & \multicolumn{2}{|c|}{ Total } & & \\
\hline & & Range & Mean & Range & Mean & Range & Mean \\
\hline Mouse & 20 & 0 & 0 & $6.65-7.20$ & 6.88 & 0 & 0 \\
\hline Rat & 9 & $0.15-0.34$ & 0.25 & $0.44-1.25$ & 0.75 & $25.0-77.3$ & 36.3 \\
\hline Guinea pig & 6 & $0.55-6.08$ & 2.23 & $0.69-6.47$ & 2.48 & $81.0-94.3$ & 89.7 \\
\hline Rabbit & 10 & $9.8-29.6$ & 17.4 & $16.0-72.0$ & 47.7 & $21.4-61.3$ & 38.4 \\
\hline Dog & 5 & $0.17-0.22$ & 0.20 & $0.54-1.14$ & 0.92 & $17.5-37.0$ & 23.7 \\
\hline Horse & 3 & $1.08-3.12$ & 1.94 & $2.20-3.44$ & 2.83 & $49.1-90.1$ & 65.4 \\
\hline Calf & 2 & $0.21-0.22$ & 0.22 & $0.40-0.72$ & 0.56 & $30.6-52.5$ & 41.6 \\
\hline Cow & 2 & $0.04-0.07$ & 0.06 & $0.43-0.64$ & 0.54 & $9.3-10.9$ & 10.1 \\
\hline Human ${ }^{a}$ & 40 & $0-0.08$ & $<0.02$ & $0.16-0.81$ & 0.42 & $0-14.7$ & $<4.8$ \\
\hline
\end{tabular}

${ }^{a}$ Cited from a previous report of the author (1).

TABLE VIII

Liver Vitamin $B_{12}$ Levels of Various Animal Species

\begin{tabular}{lccc}
\hline \hline \multirow{2}{*}{ Species } & Number of animals & Liver B12 levels $(\mu g$ per $g$ wet tissues $)$ \\
\cline { 3 - 4 } & & Range & Mean \\
\hline Mouse & 20 & $0.14-0.73$ & 0.36 \\
Rat & 9 & $0.06-0.62$ & 0.20 \\
Guinea pig & 5 & $0.95-1.20$ & 1.08 \\
Rabbit ${ }^{a}$ & 12 & $0.34-1.00$ & 0.61 \\
Dog & 5 & $0.08-0.43$ & 0.28 \\
Human ${ }^{b}$ & 18 & $0.48-1.16$ & 0.74
\end{tabular}

${ }^{a}$ Cited from a previous report of the author (9).

${ }^{b}$ Cited from a previous report of the author (10). 
form to the total in various species could be ranged in a decreasing order as follows: guinea pig, horse, calf, rabbit, rat, dog, cow, human and mouse. There was no parallelism between the total and free form levels of the serum $B_{12}$ among these species. In guinea pigs almost all of the serum $B_{12}$ consisted of the free form, and in horses more than 50 per cent of the mean total $\mathrm{B}_{12}$ level was the free form. These are a striking contrast to human and mouse sera in which the free form is hardly found more than a trace.

The liver $B_{12}$ levels of these species except horse, cow and calf were also determined with the results shown in Table VIII. As is seen from the Table, the liver $B_{12}$ levels of these species ranged similarly, and the variation among the various species was not so marked as in the serum $B_{12}$ levels. There was no significant relationship between the $B_{12}$ levels of the serum and of the liver among these species.

\section{DISCUSSION}

The total and free form levels of the serum $B_{12}$ of various animal species were determined in the present investigation. The total $B_{12}$ levels of the serum varied remarkably among the species. Comparing the mean values of each animal species, human serum had the lowest vitamin $\mathrm{B}_{12}$ level, and cow, calf, rat and dog sera had similar $B_{12}$ levels to human serum. In guinea pig and horse sera the mean total $B_{12}$ level was several times, in mouse serum about ten times and in rabbit serum about one hundred times higher than in human serum. The high $\mathrm{B}_{12}$ level of rabbit serum has already been reported by the auther $(9,11)$ and some other workers $(7,8)$. The liver $B_{12}$ levels per gram of wet tissues of the various species were similar to each other and rabbit liver was not an exception. Because liver is apparently the major storage organ of $B_{12}$, this fact can not support a simple assumption that the absorption of $\mathrm{B}_{12}$ through the intestinal tract is much more active in rabbits than in other species.

The ratios of the free form to the total $B_{12}$ levels of the serum in various species was not constant, but varied considerably among the species. The serum $B_{12}$ of various species was classified according to the mean ratios of the free form to the total into following three groups. (a) Most or more than fifty per cent of the serum $B_{12}$ consists of the free form, such as in the sera of guinea pigs and horses. (b) The free form is present in some degree but the majority of the serum $B_{12}$ consists of the bound form, such as in the sera of rats, rabbits, dogs, calves and cows. (c) Scarcely more than a trace of the free form can be found and the serum $B_{12}$ consists almost entirely of the bound form, such as in the sera of humans and mice. Wilson et al. (12) have found by Euglena assay that the total $B_{12}$ levels of monkey serum are lower than those of human serum and more than 50 per cent of the mean total $B_{12}$ level was in the free form. Thus, monkey serum appeares to belong to the first group.

It has been reported that the bound form in human serum is bound with 
the protein in $\alpha$-globulin fraction $(1,5)$, whereas the free form is recovered from $\beta$-globulin fraction by paper electrophoresis (1). The free form may not be free in the true sense of the word inasmuch as it seems to be in a loose binding with the protein in $\beta$-globulin fraction (1). By the assay organisms this binding may be splitted easily and utilized as the true free $B_{12}$, in contrast to the binding of the bound form. Although in the serum of other species, especially of guinea pigs, the nature of the free form is not yet confirmed, such binding with protein must be present to prevent loss of the serum $B_{12}$ by renal excretion. The differences of the property of the serum $B_{12}$ among various species may be due to the differences in the proportion of the two types of the $\mathrm{B}_{12}$-binding proteins present in these sera. Two types of the $\mathrm{B}_{12}$-binding proteins have been dealt with in the previous papers $(1,2)$.

Among the results obtained in the present investigation some problems remain for further studies. For example, the exact cause for such a wide variation of the total $B_{12}$ levels of the serum among various species was not understood, although it may partially account for the difference of the amount or capacity of the $\mathrm{B}_{12}$-binding proteins in these sera. The distinction in the physiological significance in animal body of both the bound and free forms of the serum $B_{12}$ is still quite obscure.

\section{SUMMARY}

Range and average values were determined for the total and free form levels of the serum vitamin $B_{12}$ of the mouse, rat, guinea pig, rabbit, dog, horse, cow and calf. Liver vitamin $B_{12}$ levels of these animal species were also determined except the horse, cow and calf. The total $\mathrm{B}_{12}$ levels of the serum had a wide variation among the various animal species. The species with the highest total $B_{12}$ level of the serum was the rabbit and the level was about one hundred times higher than that of human serum, which was lowest among the sera of the various species examined. The ratio of the free form to the total $B_{12}$ varied also widely among the species. The serum $B_{12}$ of the various species was classified by the mean ratios of the free form to the total into three groups. The liver vitamin $B_{12}$ levels of various species did not show such a remarkable diversity in contrast to the serum $B_{12}$ levels.

\section{ACKNOWLEDGMENT}

The author wishes to thank Prof. Kazuo Ogasawara for his advice and encouragement throughout the present study.

\section{REFERENCES}

1. Kato, N., J. Vitaminol. 5, 24 (1959).

2. Kato, N., ibid. 5, 35 (1959).

3. Ross, G. I. M., J. Clin. Path. 5, 250 (1952). 
4. Pitney, W. R., Beard, M. F., and Van Loon, E. J., J. Biol. Chem. 207, 143 (1954).

5. Ostrowski, W., Skargynski, B., and Zak, Z., Bull. Acad. Polon. Sci. 2, 9 (1954); Chem. Abs. 48, 1296 (1954).

6. Glass, G. B. J., Lillik, L. C., and Boyd, L. J., Blood 9, 1127 (1954) ; Nutr. Rev. 13, 136 (1955).

7. Rosentha1, H. L., and Brown, C. L., Jr., Proc. Soc. Exptl. Biol. Med. 86, 117 (1954).

8. Mattos, A. R., Nogueira, D. M., Sarin, A., and Tastaldi, H., An. Fac. Farm. Odontol. Univ. 13, 107 (1956); Biol. Abstr. 32, B, 11757 (1958).

9. Kato, N., and Murakami, S., J. Lab. Clin. Med. 54, 365 (1959).

10. Kato, N., Narita, Y., and Kamohara, S., J. Vitaminol. 5, 134 (1959).

11. Kato, N., and Murakami, S., Vitamins 13, 549 (1957).

12. Wilson, H.E., and Pitney, W. R., J. Lab. Clin. Med. 45, 590 (1955). 